\title{
CORRECTION
}

\section{Correction to: Continuous suction irrigation: prospective bacteriological study}

\author{
$\mathrm{J.} \mathrm{Cabo}^{1,4} \cdot$ Jaime Jose Morales de Cano $^{1} \cdot$ A. Fernandez Sabate ${ }^{1} \cdot$ J. Romero ${ }^{1} \cdot$ J. Casanas $^{1} \cdot$ J. Verdaguer $^{2} \cdot$ J. Ariza $^{3}$
}

Published online: 29 May 2021

(c) Springer-Verlag France SAS, part of Springer Nature 2021

\section{Correction to: Eur J Orthop Surg Traumatol (1995) 5: 75-78 https://doi.org/10.1007/BF02716223}

The original version of this article unfortunately contained a mistake. The family name of author "Jaime Jose Morales de Cano" was incorrect.

The correct given name and family name should be:

Given name: Jaime Jose.

Family name: Morales de Cano.
Publisher's Note Springer Nature remains neutral with regard to jurisdictional claims in published maps and institutional affiliations.

The original article can be found online at https://doi.org/10.1007/ BF02716223.

J. Cabo

xcabo@bellvitgehospital.cat

1 Orthopaedic Department, Hospital Bellvitge, Barcelona, Spain

2 Microbiological Department, Hospital Bellvitge, Barcelona, Spain

3 Infectious Diseases Department, Hospital Bellvitge, Barcelona, Spain

4 Gran Via Corts Catalanes, 699, 401a, 08013 Barcelona, Spain 